\title{
Profile Analysis and Growth Curve for Body Mass Index of Broiler Chickens Reared Under Different Feed Restrictions in Early Age
}

\begin{abstract}
The purpose of this study is to investigate the effect of different feed restrictions which were applied in early period on change of Body Mass Index of Ross 308 broiler chickens. For this aim we used to two different statistical methods, namely Profile analysis and Growth curves. The daily body weight and weekly body length change of chickens was collected from 7 days of age to 42 days of age. Profile analysis was used to compare differences among the groups and the Gompertz growth function was regressed from these data to estimate the growth parameters. The group profiles were not found parallel in terms of Body Mass Index $(\mathrm{P}<0.001)$ as a result of the Profile analysis. Therefore once concludes that the difference in Body Mass Index (BMI) of the animals between weeks depends on feeding regime (profiles are not parallel). The value of A and b parameter values were 0.02368 and 0.83436 for ad libitum group (AD), 0.02216 and 0.75251 for $20 \%$ feed restriction based on ad libitum group (YK), 0.02235 and 0.79656 for HG group, respectively. Inflection point (k) for HG group was fount smaller than that of the $\mathrm{AD}$ and $\mathrm{YK}$ groups. All parameter estimates and growth characteristics for chickens based on Gompertz growth model were significant $(\mathrm{P}<0.05)$.
\end{abstract}

Key Words: growth curve, profile analysis, body mass index, Gompertz function, broiler chicken

\section{Zusammenfassung}

Titel der Arbeit: Profilanalyse und Wachstumskurve des Körpermasseindexes von in der Aufzucht unterschiedlich gefütterten Broilerkücken

An 308 Broilerkücken wurde die Änderung des Körpermasseindexes (KMI) infolge Futterreduzierung während der Aufzuchtphase untersucht. Hierfür konnten sowohl die Profilanalyse als auch die Wachstumsfunktion nach Gompertz genutzt werden. Erfasst wurden bei drei Versuchsgruppen die Körpergewichte und die Körperlänge der Tiere zwischen dem 7. und 42. Tag nach dem Schlupf. Die Profilanalyse ermöglichte einen Vergleich der Unterschiede zwischen den Fütterungsgruppen, die Gompertzfunktion diente der Bestimmung der Wachstumsparameter. Die Profilanalyse ergab keine Übereinstimmung zwischen den Gruppenprofilen und dem KMI $(\mathrm{P}<0,001)$. Deshalb ist zu schlussfolgern, dass die Unterschiede im KMI der Tiere in den einzelnen Wochen vom Fütterungsregime abhängig waren (die Profile verliefen nicht parallel). Die Ungleichmäßigkeit des KMI der ad libitum-, der um 20 \% restriktiv gefütterten- und der Gruppe, welche ab dem 9. Tag kurzzeitig ohne Futter versorgt wurde, betrugen für die A und b Parameter 0,02368, 0,83436, 0,02216 und 0,75251, 0,02235 und 0,79653. Der Scheitelpunkt der Funktion (k) lag bei der letztgenannten Gruppe niedriger als bei den anderen beiden Gruppen. Sämtliche Parameterschätzwerte und Wachstumsmerkmale, welche auf der Wachstumsfunktion nach Gompertz basierten, waren signifikant.

Schlüsselwörter: Wachstumskurve, Profilanalyse, Körpermasseindex, Gompertzfunktion, Broilerkücken

\section{Introduction}

As in other economically reared animal stock, excessive fattening is undesirable for both bird health and meat quality (SHAHIN and EL AZEEM, 2005; SHAHIN and EL AZEEM, 2006). To obtain information about body fat, an index which is calculated as $\mathrm{BMI}=\mathrm{kg} / \mathrm{m}^{2}$ and called body mass index (BMI), is commonly used in practice (especially for human). The rationale behind developing this index was that "one of the basic signs of a healthy body is the harmony of weight and height ratio". A 
frequent use of the body mass index is to access how much an individual's body weight departs from what is normal or desirable for a person of his or her height. The weight excess or deficiency may, in part, be accounted for by body fat although other factors such as muscularity also affect body mass index. Body mass index was first used to get information about the relation between the weight and height of the humans (ENGELAND et al., 2007). Later, it was started to be used for some animal species. RINGDORFER (2001) reported that heavy kids had higher levels of kidney fat than light kids in Boer x Saanen kids. PALA et al. (2005) computed Body mass index for Saanen kids. However, there has been no study using this method, which is able to provide preliminary information about body fat, in the area of poultry production. From this point, computed body mass index of broiler chickens reared under three different feeding regimes, namely ad libitum group, the group with $\% 20$ feed restriction based on ad libitum group and the group that was not fed between 9 am and $3 \mathrm{pm}$ in this study. In this study, for estimating the change of body mass index values of animals depending on time, Gompertz growth curve model was used; while, for a better analysis of the differences between the consecutive weeks, profile analysis, which could provide more detailed information than repeated measurement design, was preferred (MENDEŞ et al., 2005; ERSOY et al., 2006).

Main objective of this study was to define growth characteristics of Ross 308 chicks treated with different feeding regimes in terms of BMI values using two different statistical analysis techniques.

\section{Materials and Methods}

In this study, 30 male Ross 308 broiler chickens were used. The study was carried out at the experimental rooms of Çanakkale Onsekiz Mart University Agriculture Faculty Animal Science Department. The chickens were divided into three groups: as ad libitum (AD), the group with the $20 \%$ feed restriction based on ad libitum groups (YK), and the group that was not fed between 9 am and 3 pm (HG). Feed restriction was applied to the chickens between 7 days of age to 21 days of age. From 22 days of age feed and water were offered ad libitum to the animals throughout the trial. Chickens were reared to 43 days of age. Nipple drinker and round feeder were used to satisfy of water and feed requirement of chickens. Birds were fed with starter diet between 0-3 weeks and with growth diet between 4-5 weeks and with finisher diet in the last week of the trial. The starter, growth and finisher diets of the animals included $24.09 \%$ crude protein, $2818 \mathrm{kcal} / \mathrm{ME}$ and 25.32\% crude protein, $2892 \mathrm{kcal} / \mathrm{ME}, 22.38$ $\%$ crude protein, $2912 \mathrm{kcal} / \mathrm{ME}$ respectively under intensive condition. Barn conditions (temperature, humidity ext.) were kept similar for each group. Initial body weight, body weight change and feed consumptions of chicks were determined by a balance ( $5 \mathrm{~g}$. by precision). The daily body weight (g) and weekly body weight (g) and body length $(\mathrm{cm})$ change of chickens was collected from seven days of age to 42 days of age. Body Mass Index (BMI) for each chicken was computed as follow:

$$
\mathrm{BMI}=\frac{\text { Body weight }(\mathrm{g})}{(\text { Body lenght }(\mathrm{cm}))^{2}}
$$




\section{Statistical Analyses}

Profile analysis and Gompertz growth curve function were used in analyzing the data. Gompertz growth curve was used to determine growth pattern of chickens in terms of Body Mass Index. Gompertz Growth function was defined as: $\mathrm{W}=\mathrm{A} \exp [-\exp (-\mathrm{b}(\mathrm{t}-\mathrm{k}))]$

Where, $\mathrm{W}$ is the BMI at the day $\mathrm{t}$; $\mathrm{A}$ is the maximum BMI at maturity; $\mathrm{b}$ is the rate of growth; $\mathrm{k}$ is the age (days) of the maximum daily BMI gain. The analysis was performed separately by groups.

Firstly, it was determined individual growth curves for each chicken in each group. Then, we used F test which is given in equation (2) in order to test homogeneity of individual growth curves. At the end of $\mathrm{F}$ test it was seen that growth curves were parallel both control and treatment groups $(\mathrm{P}>0.23)$. Therefore, it was concluded that overall growth model can be represent all of the chickens for three groups.

$$
\mathrm{F}=\frac{\mathrm{S}_{2} /(\mathrm{m}-1)}{\mathrm{S}_{1} /\left(\sum_{\mathrm{i}=1}^{\mathrm{m}}\left(\mathrm{n}_{\mathrm{i}}-2 \mathrm{~m}\right)\right.}
$$

Where, $\mathrm{m}$ number of days, $\mathrm{n}$ number of chickens, $\mathrm{s}_{2}$ sum of square between regression coefficients for each groups and $S_{1}$ sum of square of deviation from regression for each groups (KOCABAŞ et al., 1997).

Following linear model was used to compare groups for the growth curve parameters of body mass index (AKBAŞ et al., 2006).

$\mathrm{Y}_{\mathrm{ij}}=\mu+\alpha_{\mathrm{i}}+\mathrm{e}_{\mathrm{ij}}$

Where $Y_{i j}=$ growth curve parameters for BMI, $\mu$ =overall mean, $\alpha_{i}=$ fixed effect of the group $(\mathrm{i}=1,2,3), \mathrm{e}_{\mathrm{ij}}=$ residual error distributed as $\mathrm{N}\left(0, \sigma^{2}\right)$

Nonlinear model (1) to estimate growth curve parameters and linear model (2) to identify group differences was fit using NCSS statistical package program (HINTZE, 2001).

In the comparison of effectiveness of the model, $\mathrm{R}^{2}$, mean square error (MSE), Durbin-Watson (DW) statistic, statistic the final prediction error (Jp) and Akaike information criterion (AIC) were used (AKAIKE, 1969; HOCKİNG, 1976; SCHWARZ, 1978; LAMARE and MLADENOV, 2000;). Statistical significance of non-linear model parameters was determined using $95 \%$ asymptotic confidence intervals.

\section{Profile Analysis}

Profile analysis was used to determine the magnitude of both within-subjects (week) and between-subject (group) main effects and interactions. In this study, k-sample profile analysis was adapted to compare Body Mass Index of Ross 308 broiler chickens raised under three different feeding regimes. This allowed for the assignment of a level of statistical significant differences and the shapes of the centroids of three feeding regimes. Profile analysis is a method of comparison of groups that are experimental units to the same set of $\mathrm{p}$ measurements by examining the $\mathrm{p}-1$ slopes using multivariate analysis of variance (MANOVA) between adjacent coordinate values for mean vectors of the groups. Profile analysis is an extension of the repeated measurement and special case of MANOVA. The basic of profile analysis is a sequence comparison method for finding and aligning distantly related sequences. 
There are some reasons for the superiority of profile analysis to other methods such as repeated measurements and growth curve (MORRISON, 1995; MENDEŞ et al., 2005; ERSOY et al., 2006).

The hypothesis of parallelism can be expressed as $\mathrm{H}_{0}: \mathrm{C} \mu_{1}=\mathrm{C} \mu_{2}=\ldots=\mathrm{C} \mu_{\mathrm{k}}$

The hypothesis (4) is equivalent to the null hypothesis $\mathrm{H}_{0}: \mu_{\mathrm{z} 1}=\mu_{\mathrm{z} 2} \ldots=\mu_{\mathrm{zk}}$ in a oneway MANOVA on transformed variables $\mathrm{z}_{\mathrm{ij}}=\mathrm{Cy}_{\mathrm{ij}}$.

$\mathrm{z}_{\mathrm{ij}}$ is distributed as $\mathrm{N}_{\mathrm{p}-1}\left(C \mu_{1}, C \Sigma C^{\prime}\right)$. Since $C$ has $\mathrm{p}-1$ rows, $C \mathrm{y}_{\mathrm{ij}}$ is $(\mathrm{p}-1) \times 1$,

$\mathrm{C} \mu_{\mathrm{i}}$ is $(\mathrm{p}-1) \mathrm{x} 1$, and $\mathrm{C} \Sigma \mathrm{C}^{\prime}$ is $(\mathrm{p}-1) \mathrm{x}(\mathrm{p}-1)$.

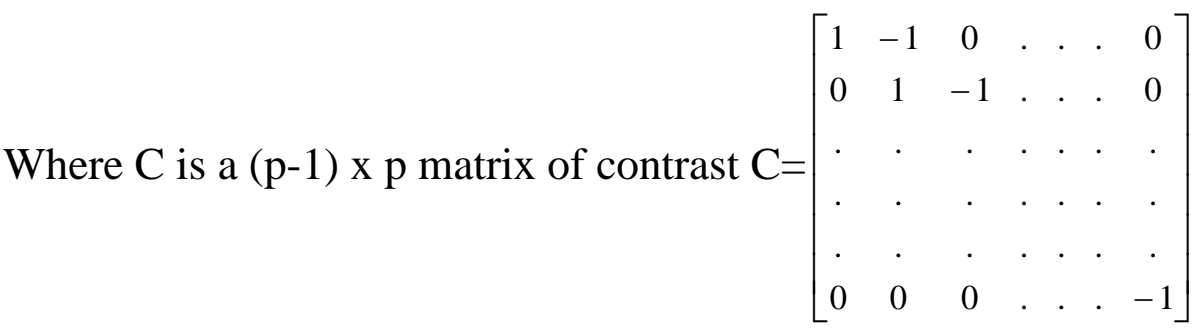

The hypothesis and error matrices for testing $\mathrm{H}_{0}: \mathrm{C}_{1}=\mathrm{C} \mu_{2}=\ldots=\mathrm{C} \mu_{\mathrm{k}}$ in (4) are $\mathrm{H}_{\mathrm{Z}}=\mathrm{CHC}^{\prime}$ and $\mathrm{E}_{\mathrm{Z}}=\mathrm{CEC}^{\prime}$. We thus have

$$
\Lambda=\frac{|\mathrm{CEC}|^{\prime}}{|\mathrm{CEC}+\mathrm{CHC}|}
$$

which is distributed as $\left(\Lambda_{\mathrm{p}-1}, \mathrm{~V}_{\mathrm{H}}, \mathrm{V}_{\mathrm{E}}\right)$.

Where $\mathrm{V}_{\mathrm{H}}=(\mathrm{k}-1)$ and $\mathrm{V}_{\mathrm{E}}=\mathrm{k}(\mathrm{n}-1)$. These calculations were based on those of RECHNER (1995).

\section{Results}

Profile Analysis

Results of Profile analysis are given in Table 1. The Wilks' Lambda and F-statistics for similar profiles or group-response interaction have the value of 0.3072 and 6.7, respectively. Therefore, once concludes that there is a significant interaction effect $(\mathrm{P}=0.001)$. In other words, the difference in Body Mass Index of the animals between weeks depends on feeding regime (profiles are not parallel). When the differences between the consecutive weeks are examined, no statistical differences in terms of the differences between 1-2 and 2-3 were found between AD and YK groups $(\mathrm{P}=0.3822)$. However, the differences of the means of these two groups from the mean of HG group were statistically significant $(\mathrm{P}=0.0021$; Table 1$)$. On the other hand, no statistical differences between the differences of 3-4, 4-5 and 5-6 weeks were found ( $\mathrm{P}>0.44$ ). Figure 1 tends to support this conclusion.

An overall evaluation is made, the means of the differences between the consecutive weeks of HG group (0.00183) were higher than AD (0.00137) and YK (0.00129) groups. Although no statistical difference was found between the AD and YK groups in terms of the differences between the consecutive weeks $(\mathrm{P}=0.4625)$, a statistical difference between the overall mean of these two groups and the mean of HG was observed $(\mathrm{P}=0.0307)$. 
Table 1

Differences among the groups for different weeks (Differenzen zwischen den Gruppen in den einzelnen Wochen)

\begin{tabular}{cccc}
\hline \multirow{2}{*}{ Sequential week Difference } & \multicolumn{3}{c}{ Groups } \\
\cline { 2 - 4 } & AD-YK & AD-HG & YK-HG \\
\hline $1-2$ & NS & $* *$ & $* *$ \\
$2-3$ & NS & $* *$ & NS \\
$3-4$ & NS & NS & NS \\
$4-5$ & NS & NS & NS \\
$5-6$ & NS & $*$ & $*$ \\
Overall & NS & & .
\end{tabular}

NS: Not significant, ** Significant at 0.01 alpha level, * Significant at 0.05 alpha level

Table 2

Descriptive statistics by groups (Beschreibende Statistik der Gruppen)

\begin{tabular}{ccc}
\hline Groups & Mean & SE mean \\
\hline AD & 0.02133 A & 0.00036 \\
YK & 0.02018 B & 0.00040 \\
HG & 0.02001 B & 0.00048 \\
\hline
\end{tabular}

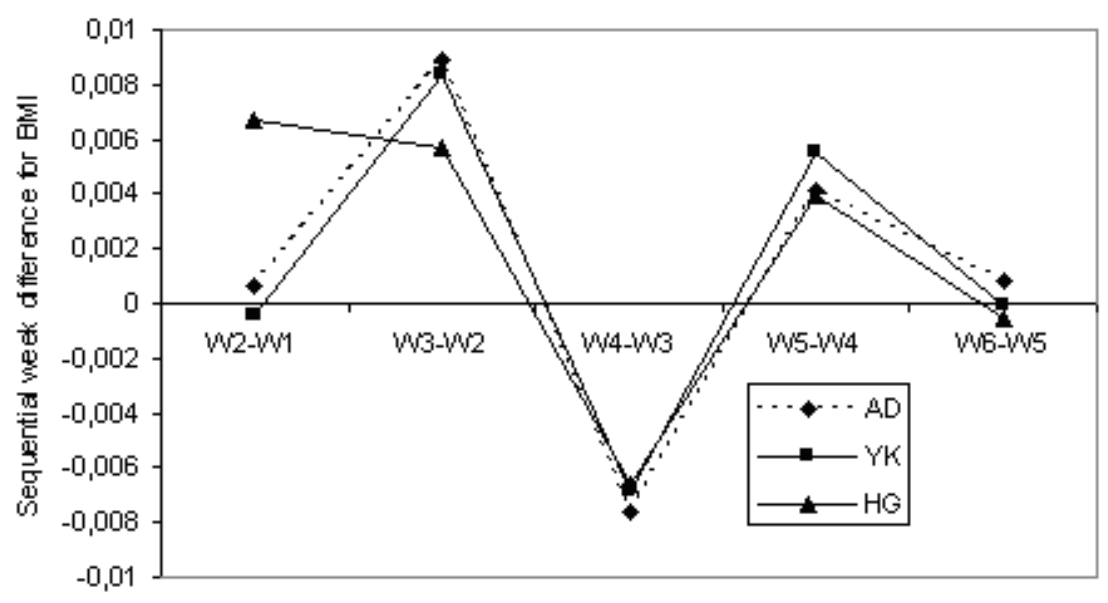

Number of sequential difference

Fig. 1: Sequential week difference by groups (Sequenzielle Wochendifferenz des Körpermasseindexes nach Gruppen)

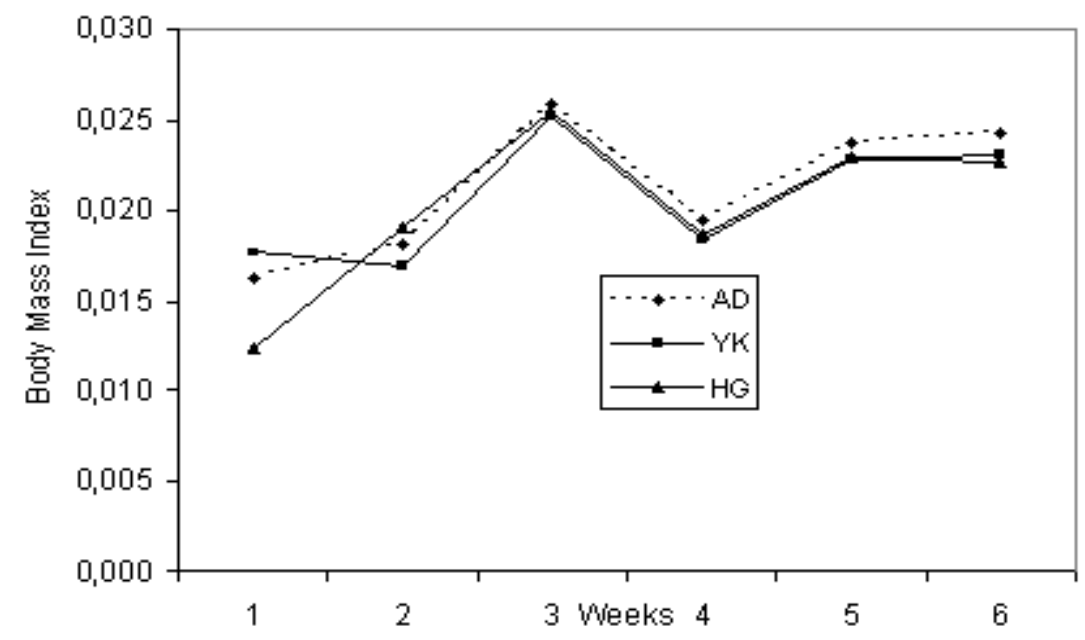

Fig. 2: Growth curve for Body Mass Index (Wachstumskurven für den Körpermasseindex nach Gruppen)

In the comparison in terms of BMI mean after 42 days of age (slaughtering age), the mean of the BMI values of HG group (0.02001) was lower as compared to AD 
(0.02133) and YK (0.02018) groups (Table 2). The difference at 42 days of age of $\mathrm{BMI}$ values of $\mathrm{YK}$ and HG groups was not statistically significant $(\mathrm{P}=0.189)$, the difference between the BMI mean of these two groups and the BMI value of AD group was observed statistically significant $(\mathrm{P}=0.001$; Table 2). Figure 1 and Figure 2 tend to support this conclusion.

\section{Growth Curves}

In this study, the Gompertz growth function was adopted to BMI-age data of Ross 308 broiler chickens reared under different feeding regimes. The parameter estimates based on Gompertz growth function are given in Table 3. Estimated parameters A, b and k showed higher values for $\mathrm{AD}$ group than $\mathrm{YK}$ and $\mathrm{HG}$ groups. The parameter value of $\mathrm{k}$ for $\mathrm{YK}$ and $\mathrm{HG}$ groups were almost same value. The average computed BMI values for $\mathrm{AD}, \mathrm{YK}$, and HG groups at 6 weeks of age were 0.02133 , 0.02018 and 0.02001 respectively (Table 2). Coefficient of determination $\left(\mathrm{R}^{2}\right)$ value for HG group (74.3\%) was higher than that of the AD (57.8 \%) and YK (54.5\%) groups. MSE value for YK group was smaller than that of the $\mathrm{AD}$ and $\mathrm{HG}$ groups. The MSE value for $\mathrm{AD}$ and HG were almost same (1.044E-05 and 1.17E-05). The DW statistic, called DurbinWatson statistic, was closer to 2 (no autocorrelation) for AD (2.13), YK (1.94), and HG (2.29) groups. Jp and AIC were used as alternative criterion for evaluating the goodness-of-fit criteria. When these two criteria were examined it was seen that the Jp and AIC values for AD (4856.08 and 712.05) and YK (4702.71 and 694.56) groups were close to each other. On the other hand both Jp and AIC values for HG group (5262.18 and 764.99) were higher than that of the $\mathrm{AD}$ and YK groups. The observed and estimated values of A parameter were close to each other for AD (0.02368), YK (0.02216), and HG (0.02235) groups. When k-parameter, an indicator of growth velocity, was examined it was seen that the estimated value of k-parameter of HG group (0.625) was smaller than that of the YK (0.655) and AD (0.706) groups.

Table 3

Parameter estimates and growth characteristics of chickens based on Gompertz growth curve (Parameter für die Wachstumsmerkmale der Kücken nach der Gompertzfunktion).

\begin{tabular}{cccc}
\hline & AD & YK & HG \\
\hline Parameter & Mean \pm SEmean & Mean \pm SEmean & Mean \pm SEmean \\
\hline A & $0.02368 \pm 0.00291$ & $0.02216 \pm 0.00331$ & $0.02235 \pm 0.00171$ \\
b & $0.83436 \pm 0.21802$ & $0.75251 \pm 0.18532$ & $0.79656 \pm 0.27653$ \\
k & $0.706 \pm 0.25$ & $0.655 \pm 0.36$ & $0.625 \pm 0.36$ \\
R $^{2}(\%)$ & 57.8 & 54.5 & 74.3 \\
MSE & $1.044 \mathrm{E}-05$ & $9.109 \mathrm{E}-06$ & $1.17 \mathrm{E}-05$ \\
Max.Week increment BMI & 0.00615 & 0.00561 & 0.00513 \\
DW & 2.13 & 1.94 & 2.29 \\
Jp & 4856.08 & 4702.71 & 5262.18 \\
AIC & 712.05 & 694.56 & 764.99 \\
\hline
\end{tabular}

\section{Discussion}

Body Mass Index $\left(\mathrm{BMI}=\mathrm{kg} / \mathrm{m}^{2}\right)$ is a calculation that uses your height and weight to estimate how much body fat you have. Most studies related to BMI are done in humans to measure obesity (SIVASLI et al., 2006; ENGELAND et al., 2007). BMI may be used as an index to evaluate nutritional status and body fat of farm animals. Obese livestock or poultry are rare and household pets have the trend to be obese. 
However, long time intensive selection and crossbreeding of broiler chickens for growth has increased growth rate but rapid growth has been accompanied by a number of negative consequences, including an increase in fat deposition (GRIFFIN, 1996; ZEREHDARAN, 2004). Decreased fat content may be desired in meat products and this can be provided with decreased BMI. The computation of BMI, therefore, for farm animals may be give valuable information about body fat, effect feeding regime on body fat and determining the optimum feeding regime. The optimum feeding regime can benefit the producer by shaving the costs related to feeding and can improve leanness of the meat, increasing its market value.

RINGDORFER (2001) reported that heavy Boer x Saanen kids had higher levels of kidney fat than light kids. In addition, feed restriction or similar stressful situations may make the BMI a useful parameter. PALA et al. (2005) reported that overconditioned goat kids (high BMI) were affected more severely from weaning stress compared to low BMI kids. The authors stated that overfeeding kids until weaning may waste valuable milk in dairy goats. The same can be stated for poultry, if ad libitum feeding results in similar weights as in restricted feeding.

Both results of profile analysis and growth curve analysis indicated that BMI value was affected by feeding regime. These two statistical methods had similar results in comparing the AD, YK and HG groups for the BMI. This indicates that the results obtained from the two methods are reliable, at least for these data. The birds in ad libitum group had more body fat than the birds with the $20 \%$ feed restriction based on ad libitum group, and the birds that was not fed between 9 am and 3 pm group. Significant differences occurred between the groups in the period of feed restriction from 7 till 21 days. It appeared that the animals in all three groups had similar BMI on day 22 onwards. This is an indicator of changes in body weight and body length based on the form of feed restriction and the impact of these changes on BMI. Since BMI is calculation is a function of body weight and body length, changes in body weight and body length affect BMI values.

It is well known that nonlinear growth functions have been used to describe the weight-age curve in chickens. Among the nonlinear growth functions, the Gompertz, the logistic and the Richards functions are popular to account for the sigmoid, asymptotic nature of the turkey, quails and chicken's growth curve (GROSSMAN and KOOPS, 1988; ANTONY, et al., 1991; KOOPS and GROSSMAN, 1991; KASSIM and BRENOE, 2002; DİNÇER et al., 2007). Gompertz function, therefore, was used in describing the growth of the chickens in terms of BMI values. The estimated value of k-parameter of HG group (0.625) was smaller than that of the YK (0.655) and AD (0.706) groups. This case may be accepting an indication that the birds in group AD and YK accumulated more fat than birds in group HG. Maximal week increment in $\mathrm{BMI}$ for the birds in ad libitum group is also higher than that of the birds in the group with the $20 \%$ feed restriction based on ad libitum group and the group that was not fed between 9 am and $3 \mathrm{pm}$. These findings suggest that the birds in group AD had more body fat than the birds in group HG and YK. That is, this case is one of the other indication of the birds in AD group had faster increase in BMI compared to birds in the YK and HG group 
AKAIKE, H.:

\section{References}

Fitting autoregressive models for prediction. Annals of the Institute of Statistical Mathematics, 21 (1969), 243-247

AKBAŞ, Y.; ALÇIÇEK, A.; ÖNENÇ, A.; GÜNGÖR, M.:

Growth curve analysis for body weight and dry matter intake in Friesian, Limousin $\mathrm{x}$ Friesian and Piemontese x Friesian cattle. Arch. Tierz., Dummerstorf, 49 (2006) 4, 329-339

ANTONY, N.B.; EMMERSON, D.A.; NESTOR, K.E.; BACON, W.L.:

Comparison of growth curves of weight selected populations of turkeys, quail and chickens. Poult. Sci., 70 (1991), 13-19

DINÇER, E.; KARABAYIR, A.; MENDEŞ, M.:

Effects of drinking water differing in dissolved oxygen concentration on growth performance of broiler. Arch. Geflügelkunde, 71 (2007) 3 (in press).

ERSOY, I.E.; MENDEŞ, M.; AKTAN, S.:

Growth Curve Establishment for American Bronze Turkeys. Arch. Tierz., Dummerstorf, 49 (2006) 3, 293-299

ENGELAND, A.; TRETLİ, S.; HANSEN, S.; BJORGE, T.:

Height and body mass index and risk Lymphohematopoietic Malignancies in two million Norwegian men and women. American Journal of Epidemiology, 165 (2007) 1, 44-52.

GRIFFIN, H. D.:

Understanding genetic variation in fatness in chickens. Annual report. Roslin Institute, Edinburgh (1996).

GROSSMAN, M.; KOOPS, W.J.:

HIINTZE, J.: Multiphasic analysis of growth curves in chickens. Poultry. Sci., 67 (1988), 33-42

HOCKING, R.R.:

The analysis and selection of variables in linear regression . Biometrics, 32 (1976), 1-49

KASSIM, O. A.; BRENOE, U.T.:

Comparing genotypes of different body sizes for growth-related traits in chickens. Live weight and growth performance under intensive feed-restricted extensive systems. Acta Agric. Scand., Sect. A.Animal Sci., 52, (2002), 1-10

KOCABAŞ, Z.; KESİCI, T.; ELIÇĊIN, A.:

Growth curve in Akkaraman, İvesi x Akkaraman and Malya x Akkaraman lambs. Turkish Journal of Veterinary and Animal Science. 21 (1997) 3, 267-275

KOOPS, W.J.; GROSSMAN, M.:

Applications of a multiphasic growth function to body composition in pigs. J. Anim. Sci., 69 (1991), 3265-3273

LAMARE, M. D.; MLADENOV, P.V.:

Modelling somatic growth in the sea urchin Evechinus chloroticus ( Echinoidea: Echinometridae). J. Exp. Mar. Biol. Ecol., 243 (2000), 17-43

MENDEŞ, M.; KARABAYIR, A.; ERSOY, I.E.; ATAŞOĞLU, C.:

Effect of three different lighting programs on live weight change of bronze turkey under semi-intensive condition. Arch. Tierz., Dummerstorf 48 (2005) 1, 86-93

MORRISON, D.F.:

Multivariate statistical Methods. Third edition. New York: McGraw-Hill Publ., (1995)

PALA, A.; SAVAŞ, T.; UĞUR, F.; DAŞ, G.:

Growth curves of Turkish Saanen Goats' Kids grouped for weight and body mass index. Arch. Tierz., Dummerstorf 48 (2005) 2, 185-193

RENCHER, A.C.:

Methods of Multivariate Analysis. New York : John Wiley \& sons Publ., (1995).

RINGDORFER, F.:

The effect of genotype, sex and final weight on slaughter performance of kids. Arch. Tierz., Dummerstorf 44 (2001) Special Issue, 385-390

SCHWARZ, G.:

Estimating the dimension of a model. The Annals of Statistics, 6 (1978), 461-464

SHAHIN, K.A.; EL AZEEM, F.A.:

Effect of breed, sex and diet and their interactions on carcass composition and tissue weight distribution of broiler chickens. Arch. Tierz., Dummerstorf 48 (2005), 612-626

SHAHIN, K.A.; EL AZEEM, F.A.: 
Effect of breed, sex and diet and their interactions on fat deposition and partitioning among depots of broiler chickens. Arch. Tierz., Dummerstorf, 49 (2006), 181-193

SİVASLI, E.; BOZKURT, A.I.; ÖZÇIRPICI, B.; ŞAHINÖZ, S.; COŞKUN, Y.:

Body mass index reference values for children aged 7-15 years in Gaziantep region. Çocuk Sağlığg ve Hastalıkları Dergisi, 49 (2006), 30-35

ZEREHDARAN, S., VEREIJKEN, A.L.J., VAN ARENDONK, J.A.M.; VAN DERWAAIJ, E.H.:

Estimation of Genetic Parameters for Fat Deposition and Carcass Traits in Broilers. Poultry Science, 83 (2005), 521-525

Received: 2007-01-25

Accepted: 2007-03-12

Authors' address

Assoc. Prof. Dr. MEHMET MENDEŞ (corresponding author); Res. Assist. ECMEL DİNÇER; ELIF ARSLAN

Canakkale Onsekiz Mart University Agriculture Faculty Animal Science Department 17020 ÇANAKKALE / TURKEY

E-Mail: mmendes@comu.edu.tr

E-Mail: edincer@comu.edu.tr 